\title{
Does constant advertising change consumer attitude?
}

\author{
Mohammed Usman \\ Department of Management, College of Economics, Management and Information Systems \\ University of Nizwa, Nizwa, Sultanate of Oman
}

\section{Keywords}

TV, Commercials; Advertising ethics; Attitude towards ads.

\begin{abstract}
It is argued that advertising must be utilitarian, however the perception of viewers' response indicate that it is far from the truth. This study investigates these issues from a consumer point of view and explores the attitudes and their perceptions towards Television advertising. For the last 25 years, there has been a massive spurt of television channels offering a plethora of programs are interceded by commercial breaks. This paper explores the attitudes of the viewer's towards television advertising. The results indicate that the information content is very low, there is too much of falsity and deceptiveness. There is no effective regulation by regulatory authorities; and much of television advertising goes unnoticed by viewers. With all these negative perceptions about advertising, the viewer's still feel that advertising is essential but not at the level that it is being telecast with so much frequency. The viewers also feel that advertising creates affluence attitude and leads to cultural degradation of society, but these issues have low priority. To conclude, advertising per se is not bad but an obsession by the advertisers will have a bad effect on the society.
\end{abstract}

Corresponding author: Mohammed Usman

Email addresses for the corresponding author: jscho@hufs.ac.kr

First submission received: $18^{\text {th }}$ March 2018

Revised submission received: $6^{\text {th }}$ July 2018

Accepted: $17^{\text {th }}$ September 2018

\section{Introduction}

Exposure to television is almost inevitable in modern life (Russell and Lane 1996). In fact, television has changed our use of time far more than any other technological development (Robinson 1990). For many, watching television has become the main leisure experience (Davies and Rojas-Mendez: 2002). Despite the growing popularity of the Internet and computer games, television is still the primary electronic medium with which children engage (Roberts et al: 2005). In the United States, there are more TV sets than there are toilets (American Psychological Association, 1993). In India, a household may not have an independent toilet or own toilet but owns a television set. Television reaches more of an advertiser's potential customers than does any other medium, and adults spend significantly more time with television than with any other medium (Television Bureau of Advertising, 2003). In recent years, the share of commercials has substantially increased. Arora (2009) quotes a market survey of 2001, which reveals that advertising has a direct influence on the consumption habits of 431 million people in India and an indirect impact on 275 million 'aspirants' from the lower income group.

\section{Attitude Towards AD (Aad)}

People are exposed to unfathomable depths of advertising. With repeated exposure to a phenomenon like television advertising, a person is said to form an attitude, which refers to a settled opinion or a way of thinking. An attitude is regarded as having two components: belief about a topic or a phenomenon followed by an evaluative factor (Lutz: 1985; Muehling: 1987). Hence the attitude towards ads starts with a belief and ends with an attitude, the latter being a summary evaluation (Pollay and Mittal: 1993). Belief is the result of frequent observation and attitude is a conclusion of belief to be true or false, positive or negative, favorable or unfavorable. One's attitude towards an object or a phenomenon shapes one's behavior (Foddy: 1993). Thus, attitude towards ad (Aad) is a process of Belief $\rightarrow$ Attitude $\rightarrow$ Behavior. 


\section{Problem Description}

Opportunities to advertise on television have grown over the past decades due to technical developments such as cable and satellite, the introduction of commercial television and the growing number of television channels (Van Meurs 1999). Consumers in the United States were on average exposed to 95 commercial messages on television per day in the year 2000 (Media Dynamics, Inc. 2002). Besides being exposed to advertising messages on television, consumers are exposed to more than one thousand commercial messages in a day (Aaker, Batra and Myers 1992). The willingness of consumers to pay attention to TV advertising is decreasing (Van Meurs 1999). Consumers are inundated with advertisements on a daily basis whether they like it or not (McClellin: 2003). Hence an understanding of the attitude towards ad (Aad) has become a research issue for the last three decades.

\section{Literature Review}

Interest in the attitude-towards-advertising-in-general gained momentum as researchers showed that it was an important underlying determinant of attitude-towards-the-ad (Lutz: 1985). Over time, the attitude towards advertising has changed and research shows that the public's opinion on advertising is mixed (Mittal, 1994; Andrews, 1989; Reid \& Soley, 1982; Bauer \& Greyser, 1968). The empirical research on Aad has been done from the viewpoint of (i) Information Content; (ii) Economic Benefits; and (iii) Social Costs. The most important studies on each of these strands of research have been presented below.

\section{(i) Information Content}

Kaldor (1950) observes: "The social function of advertising is undoubtedly the provision of information concerning the prices and qualities of goods and services available in the markets." Evidences show that advertisements are informative (Gallup: 1959; Nelson: 1974; Aaker and Stayman: 1990; Becker and Murphy: 1993; Ducoffe: 1995) and help in better decision-making by consumers (Alwitt and Prabhaker; 1992;). However, several studies find that advertising has (i) lower information content (Grossman and Shapiro: 1984;); (ii) lower information value: Mehta and Purvis: 1995); (iii) Declining information content (Pollay: 1984; Moon and Franke: 1996; Abernethy and Franke: 1998); (iv) less of information appeals and more of persuasive appeals (Chandy, Tellis, MacInnis, and Thaivanich, 2001; MacInnis, Rao and Weiss, 2002); and (v) Product misinformation (Shavitt et al: 1998).

Empirical researches on economic benefits of advertising find ads resulting in income growth (Albion and Farris: 1998); ads enhancing consumption (Ashley et al: 1980); ads stimulating demand (Mehta and Purvis: 1995; Rettie and Mojsa: 2003; Katrandjiev: 2007); Ads reducing business fluctuations (Cowling et al: 1975); and reducing the monopoly power (Becker and Murphy: 1993). Several studies find a positive association between ads and better product quality (Nelson, 1970, 1974; Milgrom and Roberts, 1986; Mehta and Purvis: 1995; Bagwell, 2005). However, several studies find an inverse relationship between ads and product quality (Schamlensee: 1978; Liefeld and Heslop: 1985; Urbany,).

With mixed results in both information content and economic benefits of television advertising, much of the research on ad perceptions has been more critical of social aspects and less of economic aspects (Ramaprasad: 2001; Larkin: 1977; Haller: 1974). An array of themes has been researched since a long time and the themes continue to expand. The discussion on social costs of television advertising unfurls with advertising being favored as an institution rather than as an instrument (Reid and Soley: 1982; Petrovici and Marino: 2007). With a few studies finding positive attitude towards advertising (Heyder, Musiol and Perters: 1992; Shavitt, Lowery and Haefner: 1998), several studies find growing negative attitudes (Barnes: 1982; Pyun and James: 2010;). The main reason for the negative attitude basically stems from the lack of trust in advertising. In this regard, Taylor and Raymond (2000) find a decrease in the trust level over the years, and Katrandjiev (2007) evidences low trust level. These conclusions are further solidified with the finding that advertisers are uneasy about truthfulness and social impact (, Zhang and Vertinsky: 2002).

Amidst this decreasing credibility in advertising, the advertisers continue to fool the people with deceptive and misleading advertisements (Nelson: 1974; Russo et al: 1981; Pollay and Mittal: 1993;) by (i) omission of material facts (Taylor and Crocker: 1981; Alba and Hasher: 1983; Johar: 1995); (ii) playing with consumer sentiments (Hoek and Maubach: 2005; Martinez et al: 2006); (iii) semantically confusing 
language or images (Alba and Hasher: 1983; Gaeth and Heath: 1987;Harris et al: 1989); (iv) expert-source misleadingness (Hastak and Maxis: 2003, 2004); (v) Shocking appeals (Dahl et al: 2003); (vi) fear appeals and arousals (Horowitz \& Gumenik: 1970;); (vii) vividness (e.g., Sherer \& Rogers, 1984); (viii) presence or absence of imagery (e.g., Shahab, Hall \& Marteau, 2007; and Hale and Dillard (1995); (ix) Too much sexual and sensual content (Boddewyn: 1991; Pardun: 2002; Katandjiev: 2007); and (x) unlimited surrogate advertising (Taylor and Raymond: 2000).

The incessant rain of television commercials has several ramifications. Basically, ads cause intrusiveness (Aaker and Bruzzone: 1985; Ha: 1996) and in fact much of advertising is irritating (GrysellL 2007). Amidst this irritation, people seem to live with it silently paving the way for their changes in value system and lifestyles through attitudinal changes.

The ill-effects of television advertising have been pronounced in ads targeting children. The unmitigated ads targeting children have resulted in (i) advertising-induced materialism and purchase requests (Moschis \& Churchill: 1978; Buijen and Valkenburg: 2003); (ii) advertising exposure leading to purchase requests by children (Atkin: 1975a, 1975b; Buijzen \& Valkenburg: 2000); (iii) advertising making children unhappy (Atkin: 1975b,1980; Richins: 1991); and (iv) parent-child conflict (Ward and Wackman: 1972; Robertson: 1979).

The negative social effects of television advertising do not stop here. In fact the ads indulge in provoking consumers through highlighting social sensitive issues like gender differences (Wolin: 20003); gender stereotyping (Milner and Collins: 2000); Feminist criticism (Kilbourne: 1990); racial stereotyping (Zhang and Shavitt: 2003); and racial discrimination: Boddewyn: 1991; Waller and Fam; 2001). The studies have also find offensive nature of ads (Aaker and Bruzzone: 1985; Li et al: 2002;); surrogate advertising of alcohol(Anderson et al: 2009) and tobacco advertising (Shah et al: 2008); and constant and exaggerated advertising of controversial products (Elena and Elliott: 2004; Waller, Fam and Erdogan: 2005; Christy and Haley: 2008).

However, people have not been the mute observers of this ugly side of advertising. They have certain set of perceptions, are influenced by the demographic variables. Empirical researches on these perceptions show a more positive attitude by middle and lower social classes than upper classes (Initiative Media and BBC World: 2002); men being more negative than women (Grusell: 2007); adults being more negative than youth (Grusell: 2007); education level influencing negatively towards ads (Grusell: 2007); youth having more positive attitude towards ads than adults (Lysonski and Pollay: 1990; Zhou, Zhang and Vertinsky: 2002); female students having more negative attitude towards advertising than male students (Petroshius: 1986; Andrews: 1989).

\section{Need for the study}

It is interesting to note that two studies by Singh and Vij (2007) and Nawathe et al (2007) have made an extensive empirical study on different dimensions of advertising ethics with restricted geographical coverage of Northern India only. As Bangalore City is the hub of economic, social and cultural milieu of the Indian sub-continent, a survey of the attitude towards television advertising seems to be more relevant and may capture the ethos of the country.

\section{Objectives of the study}

- In carrying out the empirical study, the following objectives were identified:

- To measure the economic benefits and social costs of television advertising;

- To analyze the level of falsity in television advertising;

- To examine the level of abuse of women in television advertising;

- To study the influence of television advertising on materialistic outlook;

\section{Hypotheses}

In the background of the objectives of the study, the following hypotheses were identified:

$\mathrm{H}_{1}$ : Social costs of television advertising are higher than economic benefits

$\mathrm{H}_{2}$ : Falsity in television advertising is higher than information content

$\mathrm{H}_{3}$ : Television advertising largely abuses women 
$\mathrm{H}_{4}$ : Television advertising encourages materialistic outlook in viewers

$\mathrm{H}_{5}$ : Television advertising results in cultural degradation of society and

$\mathrm{H}_{6}$ : Behavior of viewers during television commercials is more passive than active.

\section{Research methodology}

The present study is based on both primary and secondary sources of information. The secondary source of information has been extensively used to review the literature related to television advertising. The primary source of information formed the basis of empirical study. The study envisaged the perceptions of the general public by collating the responses of 451 respondents of Bangalore Urban District selected on the basis of stratified random sampling. The respondents were selected from 6 areas of Bangalore Urban District. Based on the objectives of the study and the hypotheses for the study, the responses towards television advertising were received through the structured questionnaire on 11 dimensions of advertising ethics or attitude towards advertising containing 47 statements, which were rated on 5-point Likert scale with ' 1 ' indicating 'strongly agree,' ' 2 ' indicated 'almost agree,' ' 3 ' indicating 'just agree,' ' 4 ' indicating 'almost disagree,' and ' 5 ' indicating 'strongly disagree' from sample respondents. The 'Don't Know'scale was avoided in view of definite opinions on television advertising falling into extreme positive or negative levels and many studies being conducted already without 'Don't Know' scale (Tylee: 1988; O'Donohoe: 2001). The data was collated for analysis and interpretation by mainly relying upon weighted mean value and standard deviation.

\section{Profile of respondents}

The profile of the sample respondents has been presented in Table 1, which brings out the demographic features of the respondents based on gender, age, education, income and viewing duration. Based on gender, women numbered 192 representing 42.57 per cent as against men numbering 259 and representing 57.43 per cent. From the viewpoint of age, youth numbered 268 representing 59.42 of the sample respondents as against 183 adults representing 40.58 per cent. With regard to education status, there were 337 respondents representing 74.72 per cent having low education as against 114 respondents with high education and they represented 25.28 per cent. From the viewpoint of income level, with almost equal number of respondents consisting of low-income group and high-income group with their respective numbers standing at 242 and 209 respectively and they constituted 53.67 per cent and 46.33 per cent respectively. Based on viewing duration, there were short viewers numbering 98 and representing 21.73 per cent and long viewers numbering 353 and representing 78.27 per cent. To conclude, the demographic features of respondents were characterized by a greater number of men, youth, low education, low income and long viewing durations.

\section{Analysis and interpretation}

The analysis and interpretation of data have been presented under (i) Information Content of Advertising; (ii) Economic Impact of TV Advertising; Advertising; (iii) Falsity in TV Advertising; (iv) TV Ads Creating Affluence Attitude; (v) Exploitation of Consumer Psychology; (vi) Puffery in TV Advertising; (vii) Non-Receptivity of TV Ads; (viii) Behavior during Commercials; (ix) and Ineffectiveness of TV Ad Regulation.

Table 1: Information content of TV advertising

\begin{tabular}{|c|c|c|c|c|c|c|c|c|}
\hline \multirow{2}{*}{ Advertising provides (is)... } & \multicolumn{5}{|c|}{ Frequency Distribution and Weights } & \multirow[b]{2}{*}{ Total } & \multirow[b]{2}{*}{ MV } & \multirow{2}{*}{ SD } \\
\hline & 5 & 4 & 3 & 2 & 1 & & & \\
\hline Better quality products & 38 & 52 & 96 & 204 & 61 & 451 & 2.56 & 1.12 \\
\hline Product information & 37 & 44 & 83 & 224 & 63 & 451 & 2.49 & 1.10 \\
\hline Communicative & 33 & 36 & 94 & 198 & 90 & 451 & 2.39 & 1.11 \\
\hline Right brand selections & 29 & 41 & 51 & 275 & 55 & 451 & 2.37 & 1.02 \\
\hline Prudent purchase decisions & 21 & 32 & 72 & 256 & 70 & 451 & 2.29 & 0.97 \\
\hline Total & 158 & 205 & 396 & 1157 & 339 & 2255 & 2.42 & 1.07 \\
\hline
\end{tabular}

Table 1 presents the perceptions of respondents on information content of television advertising consisting of five variables. Amongst the five variables of information content of advertising, respondents 
perceived advertised products being better in quality by assigning the highest mean value of 2.56 , which was just above half-way mark at 51.20 per cent. The least mean value was assigned to advertising helping in prudent purchase decisions with the mean value of 2.29 only. However, advertising being informative was assigned the second rank with the mean value of 2.49 , which was followed by advertising being communicative, advertising helping right brand selection with their respective mean values of 2.39 and 2.37. To conclude, the information content was found to be considerably lower even below the half-way mark with the mean value of 2.42 .

Table 2: Economic impact of TV advertising

\begin{tabular}{|l|l|l|l|l|l|l|l|l|l|}
\hline \multirow{2}{*}{ Advertising provides (is)... } & \multicolumn{2}{|l|}{ Frequency Distribution and Weights } & Total & \multirow{2}{*}{ MV } & SD \\
\cline { 2 - 9 } & 5 & 4 & 3 & 2 & 1 & & & \\
\hline Development fillip & 68 & 93 & 146 & 81 & 63 & 451 & 3.05 & 1.24 \\
& & & & & & & & \\
\hline Increased lifestyle & 53 & 85 & 166 & 102 & 45 & 451 & 3.00 & 1.13 \\
\hline Essential (at present level) & 31 & 52 & 91 & 171 & 106 & 451 & 2.40 & 1.16 \\
\hline Competitiveness in market & 28 & 32 & 41 & 268 & 82 & 451 & 2.24 & 1.03 \\
\hline A decrease in price levels & 31 & 43 & 51 & 194 & 132 & 451 & 2.22 & 1.17 \\
\hline Better products to society & 36 & 38 & 46 & 193 & 138 & 451 & 2.20 & 1.19 \\
\hline Total & 247 & 343 & 541 & 1009 & 566 & 2706 & 2.52 & 1.21 \\
\hline
\end{tabular}

Source: Field Survey.

Table 2 portrays the perceptions of the respondents towards the economic impact of advertising which consists of six variables. The respondents perceived the economic role of advertising by assigning a moderately higher mean value of 3.05 and this indicated that advertising spurred the economic development considerably. After advertising spurring the development process, the respondents perceived that it would improve the lifestyle of the people by assigning the mean value of 3.00 . On the issue of essentiality of the present level of advertising, the respondents assigned the mean value of 2.40 only and this indicated indirectly that there was too much of advertising in television. The respondents assigned a lower mean value of only 2.40 with regard to advertising enhancing the competitiveness in the market and this indirectly indicated that advertising resulted in the monopoly power to the advertiser. Further, the respondents rated whether advertising decreased the price level of the products advertised by assigned the second lowest mean value of 2.22 and this indicated that advertising unnecessarily caused an increase in the price levels of the products advertised. The least economic role of advertising was evidenced in case of advertising resulting in better products for the public with the mean value of only 2.20 and this indicated that advertising provided goods which were not useful to the community.

In total, the results indicated that advertising spurred economic development and improved the lifestyles of the people, but it failed to fulfill other economic functions like providing better products at reduced prices through enhanced competitiveness. It was found that the present level of advertising was unwarrantedly high. Lastly, the economic impact of advertising was found to be rated just a little above the information content with the mean value of 2.52 , which indicated that only half of advertising was productive, and the other half was a wasteful expenditure.

Table 3: Abuse of women in TV advertising

\begin{tabular}{|l|l|l|l|l|l|l|l|l|}
\hline \multirow{2}{*}{ Statements } & \multicolumn{2}{|l|}{ Frequency Distribution and Weights } & Total & MV & SD \\
\cline { 2 - 11 } & 5 & 4 & 3 & 2 & 1 & & & \\
\hline Advertising projects women in bad image & 123 & 115 & 152 & 34 & 27 & 451 & 3.61 & 1.14 \\
\hline Advertising exploits sexual instincts & 126 & 110 & 130 & 59 & 26 & 451 & 3.56 & 1.19 \\
\hline There is too much sex in advertising & 112 & 122 & 139 & 49 & 29 & 451 & 3.53 & 1.16 \\
\hline Total & 361 & 347 & 421 & 142 & 82 & 1353 & 3.56 & 1.16 \\
\hline
\end{tabular}

Source: Field Survey.

Table 3 presents the perceptions of respondents towards abuse of women in television advertising with three variables included under it. It was found that the abuse of women in television advertising was assigned a comparatively higher mean value of 3.56 and this indicated that women were used as sexual stereotypes. Advertising projecting women with bad image was assigned the highest mean value of 3.61, 
which was followed by the exploitation of the sexual instincts and the presence of too much sex in television advertising with their respective mean values of 3.56 and 3.53. To sum up, there was too much abuse of women in television advertising with bad image, stereotyping, sexuality and sensuality as evidenced through the mean value of 3.56 .

Table 4: Falsity in TV advertising

\begin{tabular}{|c|c|c|c|c|c|c|c|c|}
\hline \multirow[t]{2}{*}{ Statements } & \multicolumn{5}{|c|}{ Frequency Distribution and Weights } & \multirow[t]{2}{*}{ Total } & \multirow[t]{2}{*}{ MV } & \multirow[t]{2}{*}{ SD } \\
\hline & 5 & 4 & 3 & 2 & 1 & & & \\
\hline Advertisements are deceitful and misleading & 119 & 141 & 163 & 20 & 8 & 451 & 3.76 & 0.95 \\
\hline Advertisements make false claims on the uses & 118 & 137 & 167 & 20 & 9 & 451 & 3.74 & 0.96 \\
\hline Advertising exaggerates usefulness level & 125 & 129 & 139 & 37 & 21 & 451 & 3.67 & 1.10 \\
\hline Advertisements signal wrong messages & 101 & 121 & 152 & 54 & 23 & 451 & 3.49 & 1.12 \\
\hline Total & 457 & 531 & 624 & 131 & 61 & 1804 & 3.66 & 1.04 \\
\hline
\end{tabular}

Table 4 highlights the perceptions of respondents towards falsity in television advertising, in which four variables are included. It was evidenced that television advertising was characterized by falsity at a higher level with the assigned mean value of 3.66, which represented the falsity level of 73.20 per cent. The highest falsity level was identified to be deceitful and misleading advertising with the mean value of 3.76 having smaller dispersion level as against a lower level of advertisements signaling wrong messages with the mean value of 3.49 having a higher dispersion level. The second most falsity component was found to be advertisements making false claims on the uses with the mean value of 3.74 and this was followed by advertising exaggerating the usefulness level with the mean value of 3.67. On the whole, falsity in television advertising was found to be very high in the sense that all television advertisements were loaded with 73.20 per cent falsity.

Table 5: TV Ads Creating Affluence Attitude

\begin{tabular}{|l|l|l|l|l|l|l|l|l|}
\hline Statements & \multicolumn{2}{|l|}{ Frequency Distribution and Weights } & Total & MV & \multirow{2}{*}{ SD } \\
\cline { 2 - 6 } & 5 & 4 & 3 & 2 & 1 & & \\
\hline $\begin{array}{l}\text { Advertising makes people live in a world of } \\
\text { fantasy }\end{array}$ & 124 & 131 & 105 & 58 & 33 & 451 & 3.57 & 1.22 \\
\hline $\begin{array}{l}\text { Advertising encourages consume more } \\
\text { philosophy beyond one's means }\end{array}$ & & 125 & 139 & 65 & 31 & 451 & 3.40 & 1.16 \\
\hline Advertising presents luxury as a necessity & 94 & 108 & 135 & 78 & 36 & 451 & 3.32 & 1.21 \\
\hline $\begin{array}{l}\text { Advertising provides useless goods and services } \\
\text { to the society }\end{array}$ & 83 & 102 & 141 & 79 & 46 & 451 & 3.22 & 1.22 \\
\hline Total & 392 & 466 & 520 & 280 & 146 & 1804 & 3.38 & 1.21 \\
\hline
\end{tabular}

Table 5 summarizes the perceptions of respondents towards television advertisements creating affluence attitude in the society, which consists of four variables. The role of television advertising in creating the affluence attitude was assigned the mean value 3.38 characterized by a thin dispersion. The most criticized variable was found to be advertising making people live in a world of fantasy with the mean value standing at 3.57 and the least criticized variable was found to be, advertising providing useless goods and services with the mean value of 3.22, which was followed by advertising encouraging consumption of more philosophy and presenting luxury as a necessity with respective mean values of 3.40 and 3.32. To conclude, it was commonly perceived by the respondents that television advertising created more of affluence attitude in the consuming public by making them live in a world of fantasy, nurturing them with consume more philosophy, converting a luxury into a necessity and thereby providing useless goods to society. (consume more philosophy is an unclear sentence. It can confuse the readers. 
Table 6: Cultural degradation of society

\begin{tabular}{|l|l|l|l|l|l|l|l|l|}
\hline \multirow{2}{*}{ Statements } & \multicolumn{3}{|l|}{ Frequency Distribution and Weights } & Total & MV & SD \\
\cline { 2 - 11 } & 5 & 4 & 3 & 2 & 1 & & & \\
\hline $\begin{array}{l}\text { Children are indoctrinated to living with advertised } \\
\text { products }\end{array}$ & 138 & 127 & 112 & 47 & 27 & 451 & 3.67 & 1.18 \\
\hline Advertisements are offensive & 134 & 103 & 126 & 65 & 23 & 451 & 3.58 & 1.20 \\
\hline Advertising endorses stereotyping & 94 & 128 & 169 & 36 & 24 & 451 & 3.51 & 1.07 \\
\hline Most advertising distorts the values in youth & 77 & 114 & 101 & 128 & 31 & 451 & 3.17 & 1.21 \\
\hline Advertising creates violent behavior in children & 65 & 108 & 141 & 94 & 43 & 451 & 3.13 & 1.18 \\
\hline Advertising is harmful to the society & 53 & 92 & 104 & 144 & 58 & 451 & 2.86 & 1.22 \\
\hline Total & 561 & 672 & 753 & 514 & 206 & 2706 & 3.32 & 1.21 \\
\hline
\end{tabular}

Table 6 presents an overview of how television advertising causes cultural degradation of society through six variables included under the subject. The most serious problem in cultural degradation of society by television advertising was perceived to be children indoctrinated to inevitable living with advertised products with the mean value of 3.67, which was followed by advertisements (1) being offensive, (2) endorsing stereotyping; (3) distorting values in youth; (4) creating violent behavior in children with the mean values of 3.58, 3.51, 3.17, and 3.13 respectively. However, advertising being harmful to the society was rated with the lowest mean value of 2.86 and this indicated advertising per se is not bad for the society. To conclude, the impact of television advertising on cultural degradation of society was rated at higher level with the mean value of 3.32 with a moderately high dispersion level but its harmful effect on the society was rated at a considerably lower level with the mean value of 2.86 .

Table 7: Exploitation of consumer psychology

\begin{tabular}{|l|l|l|l|l|l|l|l|l|l|}
\hline \multirow{2}{*}{ Statements } & \multicolumn{2}{|l|}{ Frequency Distribution and Weights } & Total & MV & SD \\
\cline { 2 - 9 } & 5 & 4 & 3 & 2 & 1 & & & \\
\hline $\begin{array}{l}\text { Advertising indulges in manipulation of } \\
\text { consumers' minds }\end{array}$ & 148 & 134 & 116 & 28 & 25 & 451 & 3.78 & 1.13 \\
\hline Advertising forces us to react irrationally & 138 & 136 & 114 & 38 & 25 & 451 & 3.72 & 1.15 \\
\hline $\begin{array}{l}\text { Advertising develops and exploits } \\
\text { inferiority complex }\end{array}$ & 135 & 138 & 88 & 71 & 19 & 451 & 3.66 & 1.18 \\
\hline Total & 421 & 408 & 318 & 137 & 69 & 1353 & 3.72 & 1.15 \\
\hline
\end{tabular}

Television advertising as a strategy of exploiting consumer psychology has been presented in Table 7 with three variables included under it. The most serious charge against television advertising was found to be that advertising indulged in the manipulation of consumers' minds and the mean value assigned was considerably higher at 3.78 which was followed by television advertisements forcing to react irrationally and developing and exploiting inferiority complexes of the prospective users with the respective mean values standing at 3.72 and 3.66. However, dispersion levels were found to be moderately higher. To conclude, television advertising was perceived to exploit the consumer psychology at a substantial level with the mean value assignment of 3.72 and the contents of advertising were tuned to achieve the exploitation of consumers to the maximum.

Table 8: Non receptivity of TV ads

\begin{tabular}{|l|l|l|l|l|l|l|l|l|l|}
\hline \multirow{2}{*}{ Statements } & \multicolumn{6}{|l|}{ Frequency Distribution and Weights } & \multirow{2}{*}{ Total } & \multirow{2}{*}{ MV } & SD \\
\cline { 2 - 12 } & 5 & 4 & 3 & 2 & 1 & & & \\
\hline Advertisements are irritating & 145 & 135 & 153 & 13 & 5 & 451 & 3.89 & 0.93 \\
\hline Advertisements are too much repetitive & 138 & 147 & 146 & 13 & 7 & 451 & 3.88 & 0.93 \\
\hline There is too much of advertising & 124 & 141 & 126 & 39 & 21 & 451 & 3.68 & 1.10 \\
\hline $\begin{array}{l}\text { Advertising misuses the right of } \\
\text { expression }\end{array}$ & 129 & 136 & 124 & 37 & 25 & 451 & 3.68 & 1.13 \\
\hline Total & 536 & 559 & 549 & 102 & 58 & 1804 & 3.78 & 1.03 \\
\hline
\end{tabular}


Table 8 highlights the perceptions of respondents towards ads receptivity which consists of four variables. The most negative receptivity was evidenced in experiencing irritation caused by advertisements and the mean value stood at 3.89, which was followed by too many repetitive advertisements, too much of advertising, and misuse of right of expression by the advertiser and the media with their respective mean value of $3.88,3.68$, and 3.68. It was also observed that the dispersion levels were considerably lower for irritation and repetition. On the whole, receptivity of television advertisements was very much negative with the mean value of 3.78. In other words, the dislike of advertisements while viewing television was found to be almost 75.60 per se.

Table 9: Behaviour during commercials

\begin{tabular}{|l|l|l|l|l|l|l|l|l|}
\hline \multirow{2}{*}{ Statements } & \multicolumn{2}{|l|}{ Frequency Distribution and Weights } & Total & MV & SD \\
\cline { 2 - 10 } & 5 & 4 & 3 & 2 & 1 & & & \\
\hline $\begin{array}{l}\text { Switching to other channels (Channel } \\
\text { Zapping) }\end{array}$ & 254 & 117 & 63 & 14 & 3 & 451 & 4.34 & 0.88 \\
\hline Killing the sound (Muting) & 182 & 164 & 79 & 21 & 5 & 451 & 4.10 & 0.92 \\
\hline $\begin{array}{l}\text { Engaging in other works (Physical } \\
\text { zapping) }\end{array}$ & 198 & 157 & 26 & 43 & 27 & 451 & 4.01 & 1.19 \\
\hline Inattentive & 92 & 104 & 118 & 95 & 42 & 451 & 3.24 & 1.25 \\
\hline Switching off & 71 & 82 & 112 & 95 & 91 & 451 & 2.88 & 1.35 \\
\hline Total & 797 & 624 & 398 & 268 & 168 & 2255 & 3.72 & 1.26 \\
\hline
\end{tabular}

Table 9 displays data related to avoidance behaviour of television ads by the respondents through five techniques. The highest avoidance level was found in channel zapping with the mean value of 4.34 $(86.80 \%)$, which was followed by muting, physical zapping, inattentiveness, and switching off with their respective assigned mean values of $4.10(82.00 \%), 4.01(80.20 \%)$, inattentive $(64.80 \%)$, and switching off $(57.60 \%)$. It is important to note that advertisements are meant for viewing and they are pictured to be so but viewers almost never view them and this speaks of the apathy towards ads by viewers, but the stern belief of the advertisers that they will pay dividends some day through prolonged repetition. On the whole, the respondents perceived that they avoided much of advertisement through various techniques and the assigned mean value was very higher at 3.72 with moderately lower dispersion levels for channel zapping, muting, physical zapping, and higher dispersion levels for inattentiveness and switching off. In other words, the viewers avoided the advertisements to the tune of 74.40 per cent by adopting various techniques.

Table 10: Ineffectiveness of TV Ad Regulations

\begin{tabular}{|l|l|l|l|l|l|l|l|l|}
\hline \multirow{2}{*}{ Statements } & \multicolumn{3}{|l|}{ Frequency Distribution and Weights } & Total & MV & SD \\
\cline { 2 - 10 } & 5 & 4 & 3 & 2 & 1 & & & \\
\hline $\begin{array}{l}\text { Law has failed in prohibiting sexually } \\
\text { suggestive advertising }\end{array}$ & 131 & 148 & 147 & 16 & 9 & 451 & 3.83 & 0.95 \\
\hline $\begin{array}{l}\text { Advertising is not effectively } \\
\text { regulated by law }\end{array}$ & 132 & 139 & 149 & 23 & 8 & 451 & 3.81 & 0.97 \\
\hline Regulatory body is a mute observer & 145 & 126 & 132 & 30 & 18 & 451 & 3.78 & 1.09 \\
\hline Regulation of claims is non-existent & 115 & 121 & 139 & 46 & 30 & 451 & 3.54 & 1.17 \\
\hline Total & 523 & 534 & 567 & 115 & 65 & 1804 & 3.74 & 1.06 \\
\hline
\end{tabular}

Table 10 highlights the level of ineffectiveness of regulating television advertising with four variables included under it. The most serious ineffectiveness in TV ad regulation was perceived with regard to the law failing in prohibiting sexually suggestive advertisements with the mean value of 3.83, which was followed by advertising in general not effectively regulated, regulatory bodies being mute observers of misleading and deceptive advertising, and non-existence of regulation of comparative ads and research claims with their respective mean values of 3.81, 3.78 and 3.54. On the whole, respondents perceived the complete failure of regulation of television ads in prohibiting or mitigating sexually suggestive ads, inaction on misleading and deceptive advertising and non-existence of control over 
comparative ads and research claims by assigned the mean value of 3.74, which was overwhelmingly higher with moderately low dispersion levels

\section{Testing of hypotheses}

The social costs of television advertising were higher than the economic benefits with their respective mean values of 3.56 and 2.47 and hence $\mathrm{H}_{1}$ was accepted. The falsity level in television advertising was higher along with exploitation of consumer psychology and puffery than the information content with their respective mean values of 3.66, 3.72 and 3.54 than the information content with the mean value of just 2.42 and hence $\mathrm{H}_{2}$ was accepted. The abuse of women in television advertising was perceived with a substantially higher mean value of 3.56 and hence $\mathrm{H}_{3}$ was accepted. The mean value towards television advertising encouraging materialistic outlook or affluence attitude in viewers stood at 3.38 and hence $\mathrm{H}_{4}$ was accepted. The mean value rating of television advertising resulting in cultural degradation of society was substantially higher at 3.32 and hence $\mathrm{H}_{5}$ was accepted. Lastly, the behavior of viewers during commercials and non-receptivity of ads were rated with very high mean values of 3.78 and 3.72 respectively and hence $\mathrm{H}_{6}$ was accepted.

\section{Limitations of the study}

1. The present empirical study was conducted with the following limitations and hence the conclusions are to be taken cautiously:

2. The sample respondents were from Bangalore Urban District and hence the generalization of the conclusions is very much limited;

3. Only five demographic variables were included in the study and the study of other variables influencing the perceptions might have significantly different results; and

4. The study did not cover the perceptions of children because only those aged above 18 and above were considered.

\section{Discussion}

Mckinsey \& Co conducted a study in 2010 to evaluate the effectiveness of Television advertisements, it was found that there is drop of $60 \%$ as compared to 1990 . People, especially the millennials are turning towards alternative sources of entertainment, thanks to the advancement in technology and the internet. In addition, People tend mute the TV and use it as "break time" during advertisements.

Advertisements persuade customers to purchase products and services. On the other hand, the expenses of advertisement in comparisons of other activities in most companies are very remarkable. Marketing studies showed that traditional advertisement strategies based on massive ads bombarding over a generic audience are not very effective and, in some cases, are at risk of being counterproductive. As a result, marketers and advertising companies are always looking for more effective and newer communication media and evaluation methods of advertising effectiveness

The present empirical study has a number of implications on future directions in which television advertising should move. It is evident that substantial numbers of viewers do not like to view advertisements. In addition, advertisements cause a high irritation level with too much clutter. Often, the information content is very low with its moderate role in economic development. Furthermore, in the opinion of respondent's advertisements pass on false messages, are accentuated by puffery. The constant advertising results in materialistic outlook in people, especially in children. Besides, there is virtually no regulation of advertising leading to erosion of social and cultural values.

Hence what is required is an overhaul of the role of advertising wherein its level is reduced, and its contents are reformed so that advertising can play an informative as well as a developmental role.

\section{Conclusion}

The present empirical study highlights certain interesting findings. There is no doubt that the advertisers constantly try to inform, persuade or cajole the viewers through commercials to purchase their products. No doubt, television advertising has many economic benefits, but the social costs outweigh them. An interesting finding is that that people do not like to view commercials and they resort to various 
avoidance techniques, especially by switching to other channels (channel zapping). If they find roadblocking, they prefer muting and then physical zapping. Hence much of advertising goes unnoticed. But the advertisers constantly hammer the viewers with too much repetition just to make the viewers conditioned to the product on one hand and to follow the competitors' strategies. They also feel that advertising is not communicative and informative. The illusion that advertised products are better products for the public has been perceived to be a myth. With all these negative perceptions about advertising, the viewers still feel that advertising is essential but not at the level of frequency that it is being telecast. The viewers also feel that advertising creates affluence attitude and leads to cultural degradation of society, but these issues have lower priority. To conclude, advertising per se is not bad but the advertisers' obsession with it will have cancerous effects on the society. (Again Cancerous? Bad effect is better?

\section{References}

Aaker, David A., and Donald E. Bruzzone (1985). Causes of irritation in advertising, Journal of Advertising, pp 47-57.

Aaker, David A., and Douglas M. Stayman (1990). Measuring audience perceptions of commercials and relating them to ad impact, Journal of Advertising Research, pp 7-17.

Albion, M. S. and P. W. Farris (1981). The Advertising Controversy: Evidence on the Economic Effects of Advertising, Boston, MA: Auburn House Publishing Company.

Anderson, P., A. de Bruijn, K. Angus, R. Gordon and G. Hastings (2009). Impact of alcohol advertising and media exposure on adolescent alcohol use: A systematic review of longitudinal studies, pp. 229-243.

Ashley, R., C.W.J. Granger and R. Scalene (1980). Advertising and Aggregate Consumption: An Analysis of Causality, Econometrica, pp. 1149-1168

Bauer, R. A. and S. A. Greyser (1968). Advertising in America: the consumer view. Boston: Harvard University, Division of research.

Borzekowski D.L.G. and T.N. Robinson (2001). The 30-second effect: An experiment revealing the impact of television commercials on food preferences of preschoolers. Journal of the American Dietetic Association, pp.42-46.

Corey, Kenneth A., and Charles H. Patti (1979). Advertisers responses to requests for substantiation of product claims: Differences by product category, type of claim and advertising medium, The Journal of Consumer Affairs, pp. 224-235

Cowling, K., J. Cable., M. Kelly and T. McGuinness (1975). Advertising and Economic Behavior, London: The Macmillan Press, Ltd.

Condry JC. P.J. Bence and C.L. Scheibe (1988). Nonprogram content of children s television. Journal of Broadcasting and Electronic Media, pp.255-270.

Heslop, Louise A. and B. Ryans, Adrian (1980). A second look at children and the advertising of premiums, Journal of Consumer Research, pp. 414-420.

Kamins, M. A and K. Gupta (1994). Congruence between spokesperson and product type: a matchup hypothesis perspective, Psychology and Marketing, 11(6), pp.569- 586.

Kraemer, H. C., R.I. Berkowitz and L.D. Hammer (1990). Methodological difficulties in studies of obesity I: Measurement issues. Annals of Behavioral Medicine, 12, 112-118.

Levin, D., J. Peck and L. Ye (2009). Quality disclosure and competition. Journal of Industrial Economics, pp.167-196.

LaTour, M., R.L. Snipes and S.J. Bliss (1996). Don't be afraid to use fear appeals: An experimental study, Journal of Advertising Research pp. 59-67.

Liebert, R. M., (1986). Effects of television on children and adolescents. Journal of Developmental and Behavioral Pediatrics, pp. 43-48.

Meurer, M., and D.O. Stahl (1994). Informative advertising and product match, International Journal of Industrial Organization, $p p$ 12: 1-19.

Moore, David J., D. Harris, William and C. Chen, Hong (1995). Affect intensity: An individual difference response to advertising appeals, Journal of Consumer Research, Vol.22 (2), pp.154-164.

Muehling, Darrel D., (1987). An Investigation of Factors Underlying Attitude-Toward-Advertising-in-General, Journal of Advertising, 16(1), pp. 32-40.

Pollay, Richard, (1986). The Distorted Mirror: Reflections on the Unintended Consequences of Advertising, Journal of Marketing, pp. 18-36.

Preston, Ivan L., (1977). The FTC's handling of puffery and other selling claims made By Implication, Journal of Business Research, June, pp. 155-181.

Pollay, R., and B. Mittal (1993). Here's the beef: factors, determinants, and segments in consumer criticism of advertising, Journal of Marketing, pp. 99-114. 
Resnik, A., and B.L. Stern (1977). An analysis of information content in television advertising, Journal of Marketing, Vol. 41(1):50-53.

Shank, M. D. (1999). Sports marketing: A strategic perspective. Upper Saddle River, NJ: Prentice Hall Inc.

Skurnik, Ian., Carolyn Yoon, Denise C. Park, and Norbert Schwarz (2005). How warnings about false claims become recommendations, Journal of Consumer Research, pp. 713-724.

Stigler, G. J. and Becker, G. S. (1977): De Gustibus non est Disputandum. American Economic Review, pp. 76-90.

Tellis, G. \& Fornell, C. (1988), 'Relationship between advertising and product quality over the product life cycle: A contingency theory, Journal of Marketing Research 25(1), 64-71.

Urbany, Joel E., William O. Bearden, and Dan C. Weilbaker (1988). The effect of plausible and exaggerated reference prices on consumer perceptions and price search, Journal of Consumer Research, pp. 95-110.

Utter J, Scragg R, Schaaf D. Associations between television viewing and consumption of community advertised foods among New Zealand children and young adolescents. Public Health Nutr. Pp. 606-12.

Zhang, J. \& Li, H. (2007), 'Do high birth rates hamper economic growth?', Review of Economics and Statistics pp. 110117.

Zufryden, Fred S., James H. Pedrick and Avu Sankaralingam (1993). Zapping and its impact on brand purchase behavior, Journal of Advertising Research, pp. 58-66. 